\title{
Resolution of the physical features of Cushing's syndrome in a patient with a cortisol secreting adrenocortical adenoma after unilateral adrenalectomy
}

John Paul Montinola Quisumbing, ${ }^{1}$ Mark Anthony Santiago Sandoval ${ }^{2}$

${ }^{1}$ Section of Endocrinology, Diabetes and Metabolism, Department of Medicine, University of the Philippines Manila, Manila, Metro Manila, Philippines

${ }^{2}$ Section of Endocrinology, Diabetes and Metabolism, Department of Medicine, Philippine General Hospital, University of the Philippines Manila, Manila, Philippines

\section{Correspondence to} Dr John Paul Montinola Quisumbing, ipad100183@yahoo.com Accepted 15 April 2016 CrossMark Sandoval MAS. BMJ Case Rep Published online: [please include Day Month Year] doi:10.1136/bcr-2016215693

\section{DESCRIPTION}

A 37-year-old woman developed clinical manifestations of Cushing's syndrome over a span of 2 years. Physical examination revealed features that best describe Cushing's syndrome, such as wide purple striae $(>1 \mathrm{~cm})$ over the abdomen, facial plethora and easy bruisability. ${ }^{1}$ Other features observed were hypertension, moon facies, acne, a dorsocervical fat pad, central obesity and dyslipidaemia. The diagnosis of hypercortisolism was confirmed using a $1 \mathrm{mg}$ overnight dexamethasone suppression test $(19.7 \mathrm{ng} / \mathrm{dL}, \mathrm{N}:<1.8)$ and $24 \mathrm{~h}$ urine free cortisol $(185.9 \mu \mathrm{g} / 24 \mathrm{~h}, \mathrm{~N}: 3.5-45)$. A suppressed adrenocorticotropic hormone (ACTH) level $(4 \mathrm{pg} / \mathrm{mL}$, $\mathrm{N}$ : 5-20) and a lack of hyperpigmentation suggested ACTH-independent Cushing's syndrome.

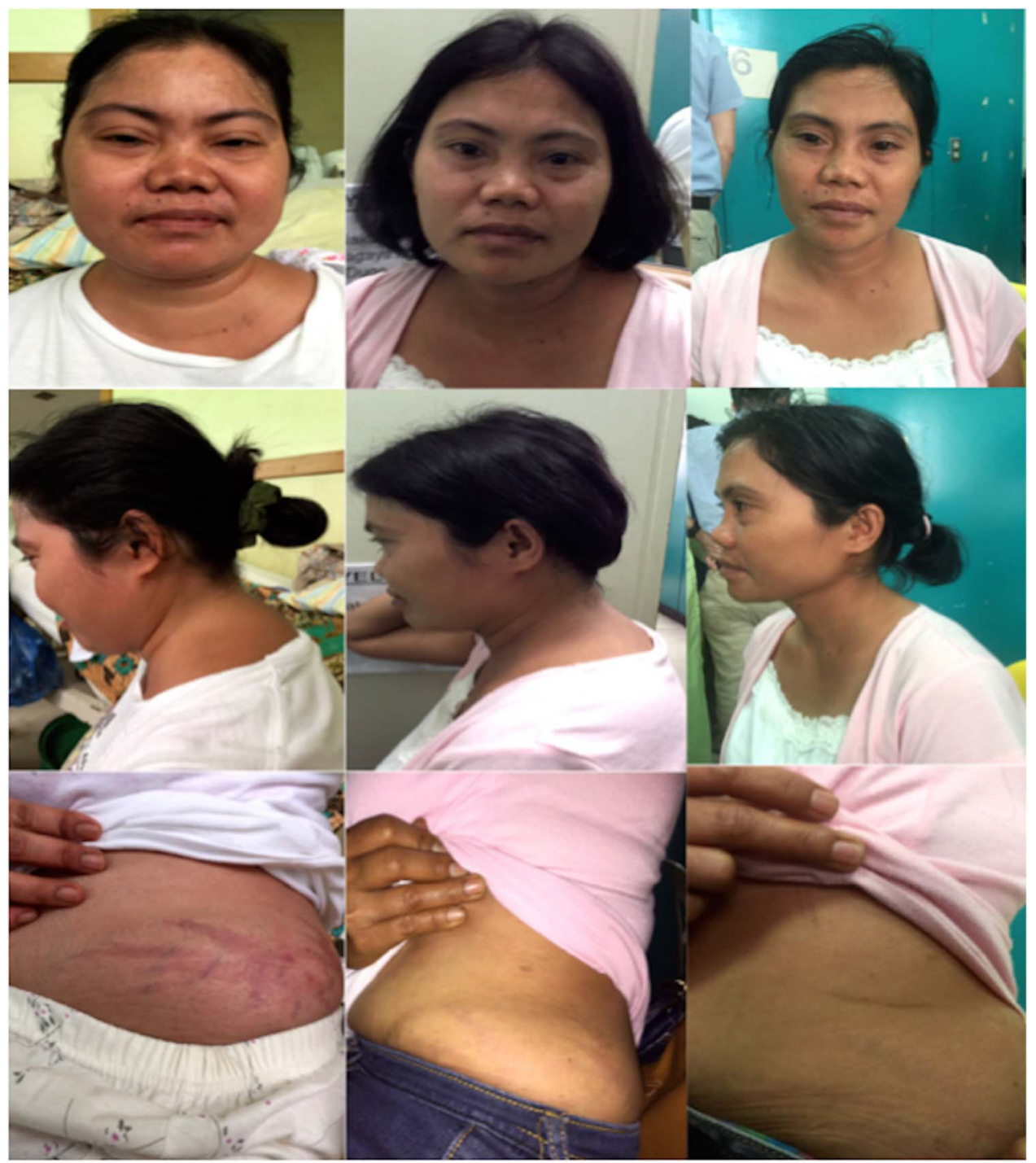

Before surgery At $\mathbf{3}$ months
At 6 months

Figure 1 Physical features of Cushing's syndrome (top to bottom: moon facies, a dorsocervical fat pad and wide purple striae $(>1 \mathrm{~cm})$ over the abdomen) documented before surgery, and at 3 and 6 months after surgery. 
Further work up using CT with contrast of the adrenals showed a $2.4 \times 2.3 \times 2.4 \mathrm{~cm}$ right adrenal mass. The patient then underwent laparoscopic adrenalectomy of the right adrenal gland. Steroids was started postoperatively and tapered over time. Histopathology results were consistent with an adrenocortical adenoma ( $2.5 \mathrm{~cm}$ widest dimension). Six months after surgery, there was resolution of the physical features, weight loss and improvement in blood pressure.

Figure 1 is a serial photograph of the physical features seen in Cushing's syndrome, such as moon facies, a dorsocervical fat

\section{Learning points}

- Physicians as well as patients should be aware that improvement of the features of Cushing's syndrome after treatment does not occur immediately.

- Dramatic resolution of the physical features of Cushing's syndrome, however, can be observed as early as 6 months after surgery. pad and wide purple striae, taken preoperatively, and at 3 and 6 months after surgery. With treatment, physical and biochemical changes of Cushing's syndrome both resolve through time. ${ }^{2}$ The time course of the resolution of these changes, however, is varied. $^{2}{ }^{3}$ We observed that the physical features were ameliorated at 3 months and resolved at 6 months.

Twitter Follow John Paul Quisumbing at @jpquisumbingmd

Contributors JPMQ worked up the case and wrote the case report. MASS reviewed the case report and critically appraised it. JPMQ incorporated his suggestions.

Competing interests None declared.

Patient consent Obtained.

Provenance and peer review Not commissioned; externally peer reviewed.

\section{REFERENCES}

1 Ross EJ, Linch DC. Cushing's syndrome-killing disease: discriminatory value of signs and symptoms aiding early diagnosis. Lancet 1982;2:646-9.

2 Sippel RS, Elaraj DM, Kebebew E, et al. Waiting for change: symptom resolution after adrenalectomy for Cushing's syndrome. Surgery 2008;144:1054-61.

3 Mishra AK, Agarwal A, Gupta S, et al. Outcome of adrenalectomy for Cushing's syndrome: experience from a tertiary care center. World J Surg 2007;31:1425-32.

Copyright 2016 BMJ Publishing Group. All rights reserved. For permission to reuse any of this content visit http://group.bmj.com/group/rights-licensing/permissions.

BMJ Case Report Fellows may re-use this article for personal use and teaching without any further permission.

Become a Fellow of BMJ Case Reports today and you can:

- Submit as many cases as you like

- Enjoy fast sympathetic peer review and rapid publication of accepted articles

- Access all the published articles

- Re-use any of the published material for personal use and teaching without further permission

For information on Institutional Fellowships contact consortiasales@bmjgroup.com

Visit casereports.bmj.com for more articles like this and to become a Fellow 